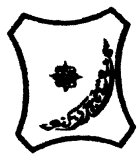

Bayero Journal of Pure and Applied Sciences, 9(2); 24 - 29

Received: June, 2016

Accepted: October, 2016

ISSN $2006-6996$

\title{
ISOLATION, PARTIAL PURIFICATION AND CHARACTERIZATION OF ANGIOTENSIN CONVERTING ENZYME FROM RAT (Rattus norvegicus) LUNGS
}

\author{
Abdulazeez, M.A. ${ }^{1}$ and Kurfi, B. G. ${ }^{2}$ \\ ${ }^{1}$ Center for Biotechnology Research, Bayero University, Kano State, Nigeria \\ ${ }^{2}$ Department of Basic Medical Sciences, Bayero University, Kano State, Nigeria \\ Corresponding Autthor: binkurfi@gmail.com +2348033105769
}

ABSTRACT

Angiotensin converting enzyme (ACE) was isolatedand partially purifiedfrom the lungs of Wistarrats (Rattusnorvegicus). The ACE was characterized and its amino acids composition determined.ACE was purified by ammonium sulphate precipitation, dialysis and gel filtration chromatography. The activity of the enzyme was assayed by a spectrophotometric method, which involves monitoring the rate of production of hippuric acid from the hydrolysis of Hippuryl-LHistidyl-L-Leucine by ACE.Protein concentration wasassayed by Biuret method; amino acid content, optimum temperature and $\mathrm{pH}$ of the isolated enzyme were also determined. From the results, the crude enzyme had a total activity of $0.12 \mathrm{U}$ and a specific activity of $0.048 \mathrm{U} / \mathrm{mg}$ of protein. Precipitation of protein increased the specific activity to $0.050 \mathrm{~V} / \mathrm{mg}$ at a recovery rate of $62 \%$. Upon dialysis, the activity of the enzyme decreased from $0.074 U$ to $0.038 U$ while specific activityalso increased. At this stage, only about $31 \%$ of the enzyme activity was retained over the crude. After gel filtration the specific activity of the enzyme increased to $0.087 \mathrm{U} / \mathrm{mg}$ at a purification fold of 1.8 and a final recovery of $25 \%$.The enzyme had an optimum $\mathrm{pH}$ and temperature of 7.0 and $40^{\circ} \mathrm{C}$, respectively. The partially purified enzyme is an oligopeptide havingseventeen amino acids:KHRDTSGPGACVMILYF. In conclusion, this study has shown that angiotensin-converting enzyme can be isolated from rat lungs, but the purification steps needs to be modified to obtain an enzyme with higher yield and specific activity that will be easily assessable for research in developing countries.

Keywords: Renin Angiotensin system, enzyme, rat lung

\section{INTRODUCTION}

$\begin{array}{lcc}\text { Angiotensin-converting } & \text { enzyme } & \text { (ACE, } \\ \text { dipeptidylcarboxypeptidase, } & \text { EC 3.4.15.1) is a }\end{array}$ dipeptidyl hydrolase and glycoprotein. ACE is widely distributed in mammalian tissues, predominantly as a membrane-bound enzyme in vascular endothelial cells, and also in several other cell types including absorptive epithelial, neuroepithelial and male germinal cells. However, ACE is a relatively nonspecific peptidase that is capable of clearing a wide range of substrates, hence, its peptide substrates and products affect many physiological processes, including blood pressure control, hematopoiesis, reproduction, renal development, renal function, and the immune response(Steve et al., 1988; Sibony et al., 1993).

ACE plays a major role in the regulation of blood pressure by virtue of two different reactions via the Renin Angiotensin Aldosterone system (RAAS): conversion of the inactive decapeptide, Angiotensin I to a powerful vasoconstrictor and salt-retaining octapeptide Angiotensin II, and inactivation of the vasodilator and natriuretic nonapeptide, bradykinin. Angiotensin II is also involved in the release of a sodium-retaining steroid, aldosterone, from the adrenal cortex which has a tendency to increase blood pressure by causing the tubules of the kidneys to increase the tubular reabsorption of sodium and hence an increased volume which also leads to an increase in blood pressure(Schmiederet al., 2007; Klabunde, 2009).

It has been demonstrated that the lungs is one of the tissues with high ACE activity due to reduced angiotensin conversion (Cushman and Cheung, 1971). The use of ACE from rabbit lungs in ACE assays has been established due to its reliability and reproducibility, but the rat is also a commonrodent. Rats are various medium-sized, long-tailed rodents of the superfamily Muroidea. "True rats" are member of the genus "Rattus". Over the years, rats have been used in many experimental studies, which have added to our understanding of genetics, disease, the effects of drugs, and other topics that have provided a great benefit for the health and wellbeing of humanity.

The Cushman and Cheung spectrophotometric assay of ACE activity determination measures the rate of production of hippuric acid from hippuryl-L-Histidyl-LLycine (HHL). Sentandreu and Toldra (2006) developed a fluorescence method, while Huggins and Thampi (1968), Hollemanset al. (1969) and Doreret al. (1970) developed the radiochemical, radioimmunoassay and the automated ninhydrin methods, respectively. 
Of these methods, the spectrophotometric method of assay using ACE from rabbit lungs described by Cushman and Cheung (1971) has been shown to be reliable and easily reproducible hence, its adoption in several studies (Wang et al., 2008; Liu et al., 2009; Cheng et al., 2009). Also, thediscrepancies in the physicochemical properties of ACE due to substrate (Bunning, 1983; Andujar-Sanchez et al., 2003) or source of enzyme (Skegget al., 1956; Gockeet al., 1969; Hooper, 1987) necessitate the isolation of the enzyme from other sources. Thus, it is pertinent to isolate and characterize ACE from rat lungs towards the possible use in ACE assays.

\section{MATERIALS AND METHODS} Chemicals and Reagents

Hippuryl-L-histidyl-L-leucine, Hydrochloric acid, Bovine Serum albumin, Ethyl acetate, Biuret reagent, Sodium Chloride, Ammonium Sulphate, Distilled water, Sephadex G-50, Potassium phosphate buffer, Sodium phosphate buffer.

\section{Animals}

Ten apparently healthy male wistar rats of about 6-8 weeks and weighing between 150-180g were purchased from the Department of Anatomy, Faculty of Medicine, Ahmadu Bello University, Zaria, Kaduna State, Nigeria. They were allowed access to water and feed (Vital Feeds, Zaria) ad libitum. All experimental protocols were assessed and approved by the Animal Use and Care Committee of Ahmadu Bello University, Zaria, Kaduna State, Nigeria.

\section{METHODS}

Angiotensin-Conversing Enzyme Activity Assay The Angiotensin converting enzyme (ACE) activity was measured by the spectrophotometric method of Cushman and Cheung (1971). The method is based on the liberation of hippuric acid from hippuryl-Lhistidyl-L-leucine $(\mathrm{HHL})$, catalyzed by ACE. The assay mixture contained $0.2 \mathrm{ml}$ of $0.3 \%(\mathrm{w} / \mathrm{v}) \mathrm{HHL}, 0.1 \mathrm{~m}$

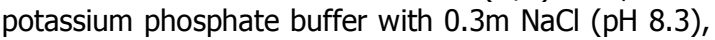
and $0.05 \mathrm{ml}$ of enzyme solution. After $15 \mathrm{mins}$ of incubation at $37^{\circ} \mathrm{C}$, the reaction was stopped by the addition of $0.025 \mathrm{ml}$ of $1 \mathrm{~N} \mathrm{HCL}$ and $2.0 \mathrm{~mL}$ ethyl acetate added to extract the hippuric acid formed by the action of ACE. This was centrifuged at $3600 \times \mathrm{g}$ for $2 \mathrm{~min}$, and $1 \mathrm{~mL}$ of upper layer transferred into a microcentrifuge tube and heated by dry bath at $100^{\circ} \mathrm{C}$ for 15 minutes to remove ethylacetate by evaporation. The hippuric acid formed was redissolved in $3 \mathrm{ml}$ of distilled water and measured spectrophotometrically at $228 \mathrm{~nm}$.

Activity in tissues was expressed in units, which corresponds to $1 \mu \mathrm{mol}$ of hippuric acid released by enzymatic hydrolysis of $\mathrm{HHL}$ per minute per milligram of tissue.

\section{Protein determination}

The protein concentration was determined by Biuret method using bovine serum albumin as standard. The mixture contained $1 \mathrm{ml}$ of the sample (containing $0.1 \mathrm{M}$ potassium phosphate buffer and $0.3 \mathrm{M} \mathrm{NaCl}$ at $\mathrm{pH} 8.3$ ) and $4 \mathrm{mls}$ of Biuret reagent. The mixture was mixed properly and incubated at $25^{\circ} \mathrm{C}$ for $30 \mathrm{mins}$ and absorbance taken at $540 \mathrm{~nm}$. The concentrations were determined from the standard curve of the bovine serum albumin.

\section{Partial Purification of ACE from Rat Lungs}

\section{Preparation of Lungs Homogenate}

The animals were sacrificed under anesthesia and dissected. The lungs were isolated, washed with icecold0.1M sodium buffer ( $\mathrm{pH}$ 7.4) and kept frozen in physiological saline to maintain an isotonic environment until required. Tissue samples were chopped and homogenized in $100 \mathrm{ml}$ of $0.1 \mathrm{M}$ potassium phosphate buffer at $\mathrm{pH}$ 8.3. The homogenate was centrifuged at $2000 \mathrm{rpm}$ for $15 \mathrm{mins}$ at $4^{\circ} \mathrm{C}$ and the resulting supernatant was then assayed for ACE activity and protein content.

\section{Ammonium Sulphate precipitation}

The supernatant was transferred into an ice-cold beaker, which was kept chilled by placing on an ice tray. The supernatant was precipitated by adding ammonium sulphate at increasingconcentrations from 30 to $80 \%$. The mixture was centrifuged at $2000 \mathrm{rpm}$ for $15 \mathrm{mins}$ at $40^{\circ} \mathrm{C}$, and the supernatant discarded leaving the pellet, which was re-dissolved in $7 \mathrm{ml}$ sodium phosphate buffer solution. The activity of ACE and protein content were determined.

\section{Dialysis}

The dialysis membrane was charged in boiling distilled water with one end of the bag clamped tightly. The membrane was filled with water, the other end tightened and then squeezed to ensure that the membrane was not leaking. The water was replaced with the enzyme sample and the open end tied again to check the integrity of the membrane which was then immersed in a beaker containing $250 \mathrm{ml}$ of potassium phosphate buffer ( $\mathrm{pH} \mathrm{8.3)} \mathrm{and} \mathrm{dialyzed} \mathrm{for}$ 24hrs with a change of buffer. After dialysis, the membrane was removed from the buffer, held vertically and excess buffer trapped in the end of the membrane outside of the clamp was removed and the sample was removed using a Pasteur pipette (Craig, 1967). Activity of ACE and protein content were determined.

\section{Gel filtration chromatography}

The dialyzed sample was subjected to gel filtration chromatography. The gel, Sephadex G-50, was soaked overnight in potassium phosphate buffer $(\mathrm{pH}$ $8.3)$. The column $(1.5 \mathrm{~cm} \times 15 \mathrm{~cm})$ was packed with the gel and washed with the same buffer. The sample was poured into the column and allowed to elute. Twenty five(25) fractions were collected and the protein content and ACE activity of each fraction determined.

\section{Characterization of ACE from Rat Lungs}

Effect of temperature on ACE activity

The partially purified enzyme was dissolved in milli-Q water and incubated with ACE. The effect of temperature on the activity of ACE was analyzed by incubating at different temperatures $(10,20,30,40$, 50,60 and $70^{\circ} \mathrm{C}$ ) for $1 \mathrm{~h}$ and determining the ACE activity.

\section{Effect of pH on ACE activity}

The effect of $\mathrm{pH}$ on partially purified ACE was determined by varying the $\mathrm{pH}$ of reaction mixture from 4 to 10 , and the ACE activity determined at the different $\mathrm{pH}$. 


\section{Determination of Amino Acid Content}

The Amino Acid profile in the known sample was determined using methods described by Benitez (1989). The known sample was dried to constant weight, defatted, hydrolyzed, evaporated in a rotary evaporator and loaded into the Technicon sequential Multi-Sample Amino Acid Analyzer (TSM).

\section{RESULTS}

Purification, Activity Assay and Protein Concentration of ACE

The steps involved in the purification of angiotensin converting enzyme are summarized in table 1 below. The crude enzyme had a total activity of $0.12 \mathrm{U}$ and a specific activity of $0.048 \mathrm{U} / \mathrm{mg}$ of protein. Precipitation of the crude enzyme caused an increase in the specific activity to $0.050 \mathrm{U} / \mathrm{mg}$ at a recovery rate of $62 \%$. Upon dialysis, the total activity of the enzyme decreased to 0.038 Uwhilespecific activity increased. At this stage, only about $31 \%$ of the enzyme activity was retained. Gel filtration gave a specific activity of $0.087 \mathrm{U} / \mathrm{mg}$ of protein at a purification fold of 1.8 and a final recovery of $25 \%$ was achieved.

The figure below (figure 1)shows the ammonium sulphate precipitation chart of ACE from rat lungs. The results showed that precipitation increased ACE activity as concentration of ammonium sulfate increased from $30 \%$ to $70 \%$, but decreased at $80 \%$. At $70 \%$ saturation, the activity of ACE was highest indicating that most of the ACE was precipitated.

Gel filtration chromatography of ACE obtained from rat lungs showed fraction 12 having the highest ACE activity and lowest protein content.Fraction 7 was found to contain the highest protein content, but ACE activity was low. Fraction 12 was chosen (figure 2 ).

Table 1: Purification table of angiotensin converting enzyme from rat lungs

\begin{tabular}{llllll}
\hline & $\begin{array}{l}\text { Protein } \\
(\mathbf{m g} / \mathbf{m l})\end{array}$ & $\begin{array}{l}\text { Activity } \\
\mathbf{( U )}\end{array}$ & $\begin{array}{l}\text { Specific } \\
\text { Activity(U/mg) }\end{array}$ & $\begin{array}{l}\text { Purification } \\
\text { Fold }\end{array}$ & $\begin{array}{l}\text { Percentage } \\
\text { Yield (\%) }\end{array}$ \\
\hline $\begin{array}{l}\text { Crude } \\
\left(\mathrm{NH}_{4}\right)_{2} \mathrm{SO}_{4}\end{array}$ & 2.515 & 0.120 & 0.048 & 1.00 & 100 \\
$\begin{array}{l}\text { Precipitation } \\
\text { Dialysis }\end{array}$ & 0.149 & 0.074 & 0.050 & 1.04 & 62 \\
Gel Filtration & 0.681 & 0.038 & 0.056 & & \\
\hline
\end{tabular}

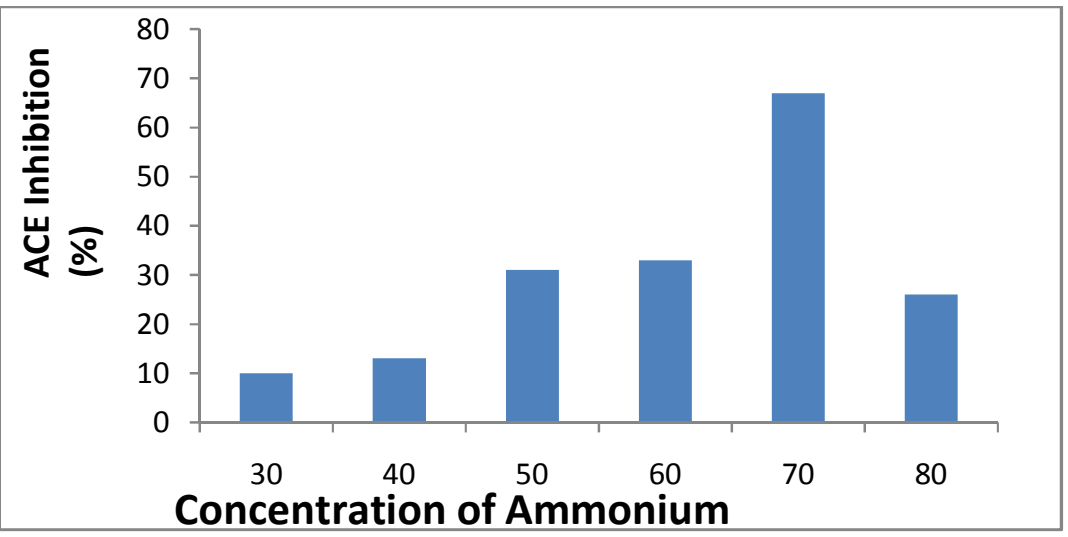

Sulphate (\%)

Figure 1: Ammonium sulphate precipitation chart of angiotensin converting enzyme from rat lungs.

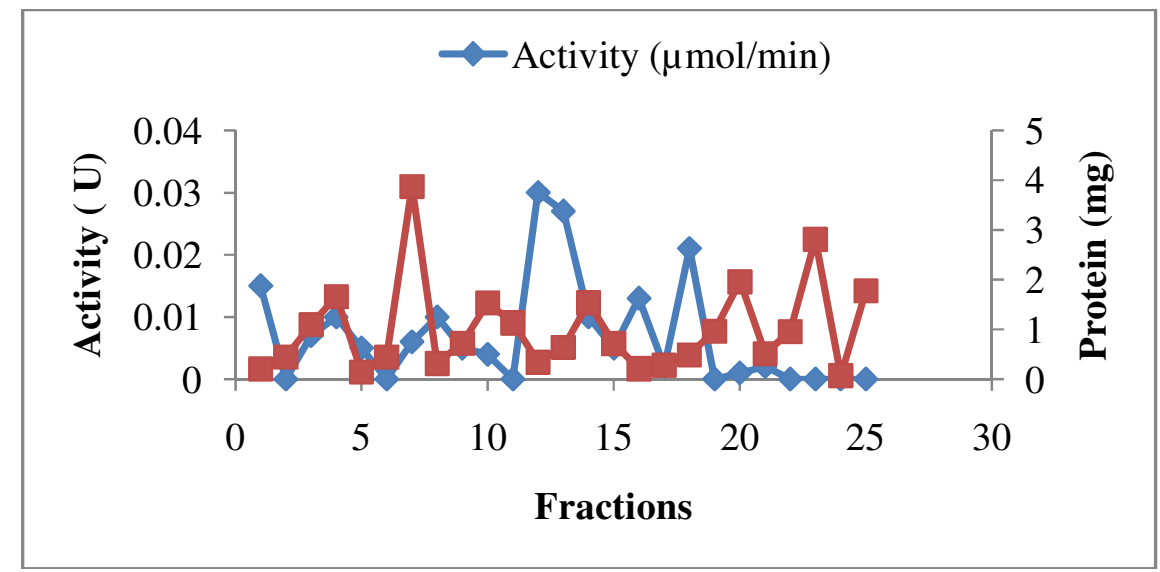

Figure 2: Elution profile of angiotensin converting enzyme from Sephadex G-50 Gel chromatography 
The optimum $\mathrm{pH}$ and temperature of the ACE from rat lungs were 7 and $40^{\circ} \mathrm{C}$, respectively. Initially, there was no activity observed at pH 4, but ACE activity increased as $\mathrm{pH}$ of the enzyme solution increased, until it reached $\mathrm{pH} \mathrm{7,} \mathrm{after} \mathrm{which} \mathrm{the} \mathrm{activity}$ decreased (figure 3). With respect to temperature, the pattern was also same, as ACE activity increased with temperature, until the optimum temperature, then a decrease was observed (Figure 4).

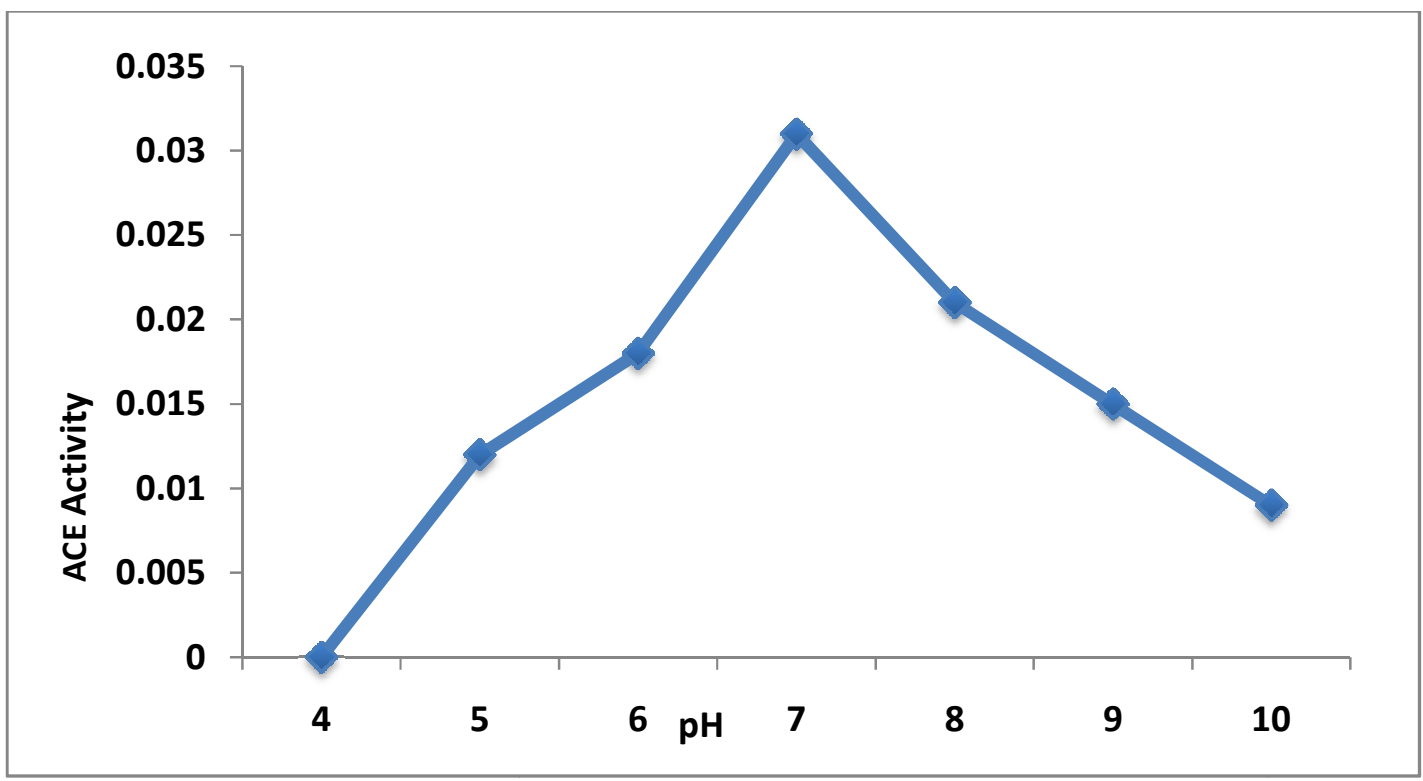

Figure 3: Effect of $\mathrm{pH}$ on the activity of angiotensin converting enzyme obtained from rat lungs

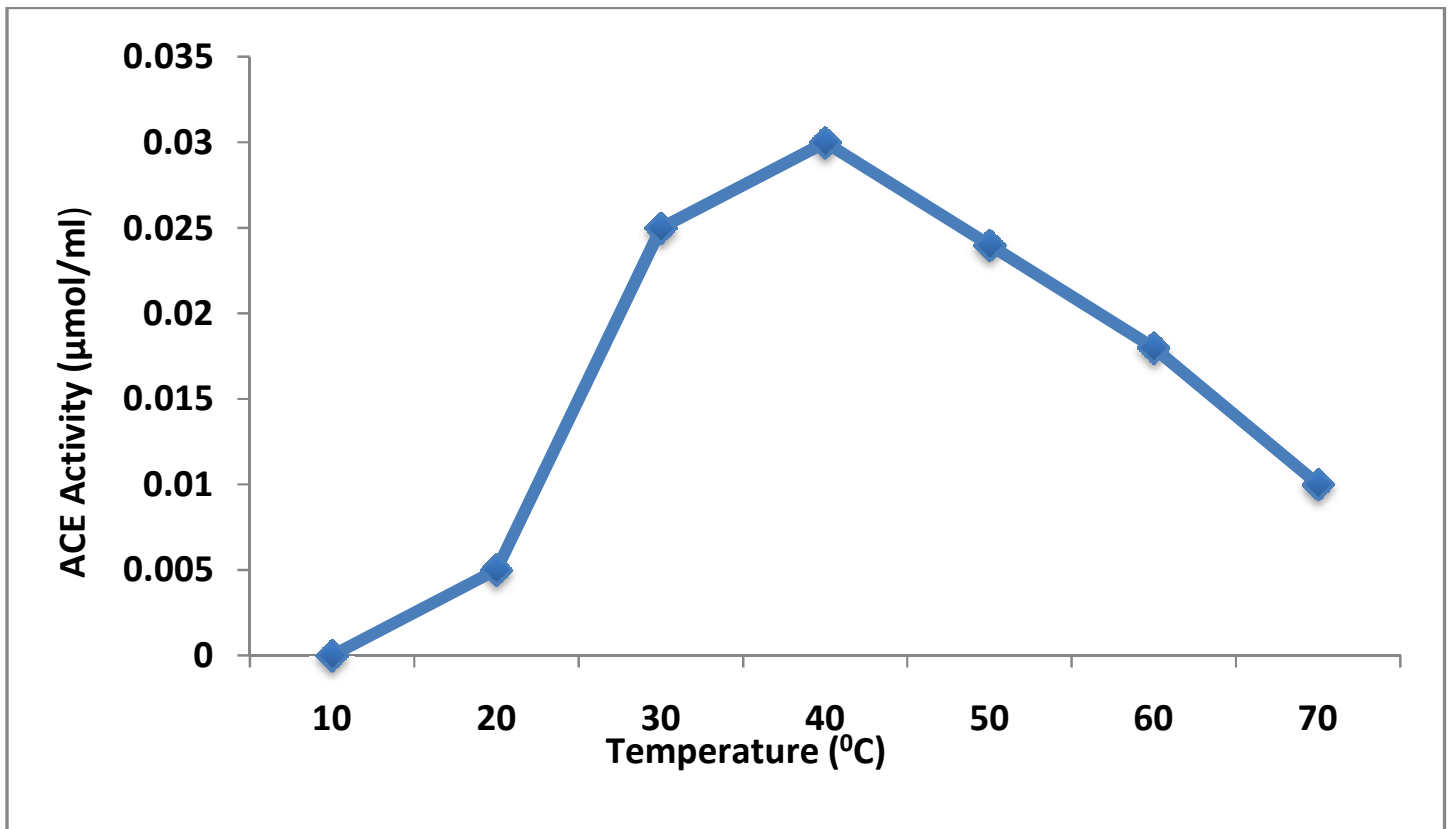

Figure 4: Effect of temperature on the activity of angiotensin converting enzyme obtained from rat lungs

From the amino acid profile, the partially-purified ACE from rat lung contained seventeen (17) amino acids: KHRDTSGPGACVMILYF. Glutamic acid concentration $(10.60 \mathrm{~g} / 100 \mathrm{ml})$ was highest followed by Aspartic
$(8.62 \mathrm{~g} / 100 \mathrm{ml})$ acid and Leucine $(7.18 \mathrm{~g} / 100 \mathrm{ml})$, while the amino acid with the lowest concentration was Methionine (Table 2). 
Table 2:Amino acid composition of partially-purified ACE from rat lung

\begin{tabular}{ll}
\hline Amino Acid & Concentration $\mathbf{( g / 1 0 0 m l )}$ \\
\hline Lysine & 3.70 \\
Histidine & 2.08 \\
Arginine & 5.26 \\
Aspartic Acid & 8.62 \\
Threonine & 3.01 \\
Serine & 2.85 \\
Glutamic acid & 10.60 \\
Proline & 2.85 \\
Glycine & 3.84 \\
Alanine & 3.99 \\
Cysteine & 1.06 \\
Valine & 4.11 \\
Methionine & 0.83 \\
Isoleucine & 2.66 \\
Leucine & 7.18 \\
Tyrosine & 2.38 \\
Phenylalanine & 3.63 \\
\hline
\end{tabular}

\section{DISCUSSION}

In this study, ammonium sulphate precipitation of the crude enzyme gave the highest activity at $80 \%$ saturation and a purification fold of 1.04 was obtained. Dialysis produced a specific activity of $0.056 \mathrm{U} / \mathrm{mg}$ and a purification fold of 1.17 over the crude extract. The increase in specific activity may be due to the removal of low molecular weight contaminants. Gel filtration chromatography (Sephadex G-50) on the dialyzed protein produced an increase in specific activity of $0.087 \mathrm{U} / \mathrm{mg}$ at a recovery of $25 \%$. This result was in close agreement with the result obtained by Sharma and Singh (1988), who purified ACE from bovine serum plasma by Sephadex G-200 and obtained a specific activity of $0.05 \mathrm{U} / \mathrm{mg}$,but lower than 30.9 and $21.6 \mathrm{U} / \mathrm{mg}$ reported by Cushman and Cheung (1971) and Bunning et al. (1983). It was also much lower than ACE purified from rabbit lungs by Abdulazeez et al. (2013). These differences may be attributed to the different enzyme source and substrates used during the assay.

The optimal $\mathrm{pH}(7.0)$ and temperature $\left(40^{\circ} \mathrm{C}\right)$ of the partially purified rat lung ACE shows that changes in $\mathrm{pH}$ and temperature may affect the activity of the enzyme. Although, this does not conform to studies by Cushman and Cheung (1971), it has been shown that under normal physiological conditions, ACE will exhibit $60 \%$ of its maximal activity, and activity increases as $\mathrm{pH}$ is increased (Bunning, 1983). This enhances the enzymatic reaction by the general base catalytic mechanism (Cushman and Cheung, 1971).

\section{REFERENCES}

Abdulazeez, M., Aimola, I.A., Rukerwe, O.A. and Abdullahi, S. (2013): Isolation, partial purification and characterization of angiotensin converting enzyme from rabbit (Oryctolagusciniculus) lungs. American Journal of Drug and Development, DOI: 10.3923/ajdd.2013.

Andujar-Sanchez, M., Camara-Artigas, A. and JaraPerez, V. (2003).Purification of angiotensin I converting enzyme from pig lung using
The partially-purified ACE peptide containedseventeen (17) amino acids. The high amino acid concentration of Glutamic acid and low Methionine conforms to studies by Liu and Chen (2000) who isolated hog ACE. Also, the partially purified oligopeptide from rat lungs obtained in this study contains Aspartic acid, Glutamic acid, Tyrosine, Arginine and Lysine. These amino acids have been demonstrated to be beneficial for the catalytic activity of the enzyme, and are located at the active site (Bunning, 1983). The enzyme was inactivated in the presence the carboxyl group reagent, 1-cyclohexyl-3-(2-morpholinoethyl)carbodiimide, which modifies the carboxyl group of Aspartate and Glutamate residues. Also, when treated with the tyrosyl reagent, tetranitromethane, Tyrosine residues are modified, and ACE activity decreased. ACE is also inactivated by butanedione and phenylglyoxal, both of which cause Arginine modification (Bunning et al., 1983).

\section{CONCLUSION}

ACE has been isolated and partially purified from different sources and different assay methods in the past. The results from this work has shown that ACE can also be isolated and partially purified from rat lungs and its activity assayed.

\section{Author's contribution}

Abdulazeez A.M. designed the study and wrote the first draft of the manuscript. Both authors carried out the laboratory work and managed the statistical analysis. All authors read and approved the final manuscript.

concanavalin-A

chromatography. Journal

sepharose ChromatographyB, 783: 247-252.

Benitez, L.V. (1989): Amino Acid and fatty acid profiles in aquaculture nutrition studies. in S.S. De Silva (ed.) Fish Nutrition Research in Asia. Proceedings of the Third Asian Fish Nutrition Network Meeting. Asian fish. Society Special Publication.Asian Fisheries Society, Manila Philippines.Pp 23- 35. 
Bunning, P. (1983): The catalytic mechanism of angiotensin converting enzyme. Clinical and Experimental Hypertension: Theory and Practice, A5(7\&8): 1263-1278.

Bunning, P., Holmquist, B. and Riordan, J.F. (1983). Substrate specificity and kinetic characteristics of angiotensin converting enzyme. Biochemistry, 22: 103-110.

Craig, L.C. (1967): Techniques for the study of peptides and proteins by dialysis and diffusion. Methods in Enzymology, 11: 870905.

Cushman, D.W. and Cheung, H.S. (1971): Spectrophotometric assay and properties of angiotensin converting enzyme from rabbit lungs. Biochemical Pharmacology, 20(7): 1637-48.

Dorrer, F.E., Skeggs, L.T., Khan, J.R., Lentz, K.E. and Levine, M. (1970). Angiotensin converting enzyme. Analytical Biochemistry, 33: 102.

Erdos, E.G. and Skidgel, R.A. (1987): The angiotensin-1-converting enzyme. Laboratory Investigation, 56: 345-8.

Gocke, D.J., Gertin, J., Sherwood, L.M. andLaragh, J.H. (1969). Physiological and pathological variations of plasma angiotensin II in man.Correlation with renin activity and sodium balance. Circulation Research, 25: 131-46.

Hollemans, H.G.J., Van Der Meer, J. and Kloosteriziel, W. (1969). Measurement of renin activity in plasma by radioimmunoassay for angiotensin I. ClinicaChimicaActa, 23: 7.

Hooper, N.M., Keen, J., Pappin, D.J.C. and Turner, A.J. (1987). Pig activity angiotensin converting enzyme. Biochemical Journal, 247: 85-93.

Huggins, C.G and Thampi, N.S. (1968): A simple method for the determination of angiotensin converting enzyme. Life Science, 7(Part II):633-639.

Klabunde, R.E. (2009): Angiotensin converting enzyme inhibitors. Available from http://www.cvpharmacology.com/vasodilator LACE.htm [Accessed 4 September 2010].

Liu, H. and Chen, L. (2000): Purification and characterization of angiotensin converting enzyme. Chinese Journal of Biochemistry and Molecular Biology, 16(6): 788-792.

Sharma, M. and Singh, U.S. (1988). Molecular and catalytic properties of angiotensin converting enzyme-I from bovine seminal plasma. Journal of Biochemistry,104 (1): 5761

Schmieder, R.E., Hilgers, K.F., Schlaich, M.P. and Schmidt, B.M. (2007): Renin-angiotensin system and cardiovascular risk. Lancet, 369: 1208-1219.

Sibony, M., Gasc, J.M., Soubrier, F., Alhenc-Gelas, F. and Corrol, P. (1993): Gene expression and tissue localization of the two isoforms of angiotensin converting enzyme. Hypertension, 21: 827-835.

Setandreu, M.A and Toldra, F. (2006): A rapid, simple and sensitive method for determination of angiotensin converting enzyme activity. Food Chemistry, 97: 546-554.

Steve, B.R., Fernandez, A., Kneer, C., Cerda, J.J., Philips, M.I. and Woodward, E.R. (1988):Human intestinal brush border angiotensin converting enzyme activity and its inhibition by antihypertensive ramipril. Gastroenterology, 98: 942-944.

Skeggs, L.T., Kahn J.R. and Shumway, N.P.(1956). The preparation and function of angiotensinconverting enzyme.Journal of Experimental Medicine, 103: 295-299. 